\title{
Impact of Banc Assurance on Customers in Purchasing Insurance Policies with Special Reference to Kurnool District of Andhra Pradesh
}

\author{
T. Narayana Reddy, K. Pushpa Latha
}

\begin{abstract}
Banking industry has grown quickly all over the world, at the same time insurance industry has also grown rapidly in the same cut throat economic environment. With the entry into non core products or services like insurance and securities markets, these days banks have increased their businesses. The integration of financial markets, emergence of new technologies and expansion of non-banking activities has a great impact on baking operations. Thus it results in opening doors for the business of non core products like insurance and securities (banc assurance) by banks. The only intention behind this diversification of business by the banks is to provide ample investment alternatives to the common people who do not have access to various financial products and securities so that they can maximize the returns on their investment. The increasing popularity of banc assurance has widened the scope of research in this area. In this study an attempt is made to know the impact of banc assurance on customers while they made decisions to purchase the insurance policies.
\end{abstract}

Key Words-Banc assurance, noncore products, integration of financial markets, investment opportunities

\section{INTRODUCTION}

Now a day's banc assurance is the buzz word. Where in banks provide a platform to insurance companies to sell their products both life and non life (general). In fact it is more cheap and cost effective rather than selling through agencies and brokers. The expected revenue generation through bank assurance is 13 to $15 \%$ in the coming five years. In, India many insurance companies have realised the importance of banc assurance and tied up with commercial, co operative and rural banks to reach more customers and subsequently they closed the doors for traditional ways of selling policies. The booming market has even drawn the attention of foreign players to enter into Indian market so that they can easily penetrate in the market without putting much effort.

\section{REVIEW OF LITERATURE}

It includes the past studies undertaken in the field of banc assurance and has been reviewed in the same context before conducting this research study.

Carson (2002) ${ }^{\mathbf{1}}$ observed that due to commission system of agents there is always a conflict in insurance distribution. Researchers tried to examine the impact of commission system of agents on the product recommendations and found that the life span and mode of policy are not related to their commission rather than bulk of recommendations was for the trustworthy behaviour of the agents. Recommendation given by agents to customers influences the purchasing behaviour of the customers.

Ostaszewski $(\mathbf{2 0 0 3})^{2}$ narrated that life insurance business is meant for security to human wealth and health and these are the financial tools for the insurance business. $\mathrm{He}$ proposed that the products like life insurance, disability insurance, annuities, and casual losses should be implemented well to discourse the doubts and shortcomings of the end users. This article recommended that these items can be seen as derivatives instruments made to address the instabilities and deficiencies of human capital, if human capital is seen as financial instrument

Chevalier, Launay, and Mainguy (2005) ${ }^{3}$ tried to draft overall banc assurance around the world. Authors made an effort to identify the causes of failure in "Anglo-Saxon" countries (Germany, Britain and America) where the role of banc assurance is now insignificant and needs to develop again on another base. They found positive factors that would determine where banc assurance is succeeding. In European countries banc assurance is now dominating and thus the banks and insurance industries are being rewarded by the banc assurance.

\section{OBJECTIVE OF THE STUDY}

To analyse the impact of bancasuurance and examine the factors that motivates the customers while making purchase decisions. 


\section{ANALYSIS AND RESULTS A. PERCENTAGE ANALYSIS}

4.1. Awareness of the customers towards banc assurance

\begin{tabular}{|l|c|c|c|c|}
\hline \multicolumn{1}{|c|}{ Particulars / Parameters } & Fully aware & Partly aware & Unaware & Total \\
\hline Premium Range & 80 & 34 & 11 & 125 \\
\hline Accessibility & 72 & 35 & 17 & 125 \\
\hline Service Charges & 120 & 2 & 3 & 125 \\
\hline Medical Checkups & 71 & 41 & 13 & 125 \\
\hline Age Limit & 45 & 61 & 19 & 125 \\
\hline
\end{tabular}

Source: (Primary data)

From the table 4.1 it clear that 96.0 percent of the respondents are fully aware of the service charges levied by the bankers for the purpose of banc assurance, 56.8 per cent of the respondents are fully aware of the medical examination procedures conducted by the banks at the time of registration of banc assurance, 56.8 percent of the respondents are fully aware of the flexibility of procedures followed by the bank, 58.4 percent of the respondents are partly aware of the level of protection given by banks, 48.8 per cent of the respondents are partly aware of the age limits fixed by the banks, 40.0 per cent of the respondent are partly aware of the premium level fixed by banc assurance.

\subsection{Acceptability of the customers towards the factors that motivate them to select banc assurance}

\begin{tabular}{|l|c|l|l|l|c|l|}
\hline \multicolumn{1}{|c|}{$\begin{array}{c}\text { Particulars / } \\
\text { Parameters }\end{array}$} & $\begin{array}{c}\text { Strongly } \\
\text { Agree }\end{array}$ & Agree & Moderate & Disagree & $\begin{array}{l}\text { Strongly } \\
\text { Disagree }\end{array}$ & Total \\
\hline Reputation of Bank & 65 & 43 & 14 & 3 & 0 & 125 \\
\hline Quality of Service & 21 & 50 & 43 & 11 & 0 & 125 \\
\hline Convenience & 12 & 25 & 43 & 20 & 25 & 125 \\
\hline $\begin{array}{l}\text { Pressure from bank } \\
\text { staff }\end{array}$ & 24 & 23 & 20 & 24 & 34 & 125 \\
\hline $\begin{array}{l}\text { Pressure from } \\
\text { relatives }\end{array}$ & 1 & 1 & 10 & 79 & 34 & 125 \\
\hline
\end{tabular}

Source: (primary data)

From the table 4.2 depicts that 63.2 per cent of the respondents have disagreed to the point that pressure from relatives and friends have motivated them to take banc assurance, 52.0 per cent of them have strongly agreed that the cordial reputation of their bank have motivated them to take up banc assurance, 40.0 per cent of the respondents have agreed that the quality of service given by bank have motivated them to take banc assurance, 34.4 per cent of the respondents have moderately agreed that they feel convenient in taking up insurance from banks, 27.2 per cent of the respondents have strongly disagreed that they do not get any kind of pressure from bank staffs to take up banc assurance.
Null Hypothesis (H0): There is no significant difference between awareness of the customers towards banc assurance and demographic variables like age, educational qualification, number of members in family, number of earning members in family, family monthly income, occupational status and area of residence.

Alternative to Null Hypothesis (H1): There is no significant difference between awareness of the customers towards banc assurance and demographic variables like age, educational qualification, number of members in family, number of earning members in family, family monthly income, occupational status and area of residence.

\section{B. Analysis of Variance (ANOVA)}

\subsection{Awareness of the customers towards banc assurance Vs. Demographic variables}

\begin{tabular}{|c|c|c|c|c|c|c|c|}
\hline $\begin{array}{c}\text { Demographic } \\
\text { variables }\end{array}$ & SOURCE & MEAN & SD & NO. & $\begin{array}{c}\text { SIGNIFICANT } \\
\text { VALUE }\end{array}$ & F & Sig. \\
\hline \multirow{4}{*}{ Age } & $18-25$ years & 2.3421 & 0.37341 & 19 & & & \\
\cline { 2 - 8 } & $26-35$ years & 2.3733 & 0.42236 & 25 & 0.921 & \multirow{2}{*}{0.164} & \multirow{2}{*}{ NS } \\
\cline { 2 - 9 } & $36-45$ years & 2.4167 & 0.48378 & 36 & & & \\
\cline { 2 - 9 } & Above 45 years & 2.3963 & 0.43724 & 45 & & 3.543 & \\
\hline \multirow{2}{*}{$\begin{array}{c}\text { Educational } \\
\text { Qualifications }\end{array}$} & Illiterate & 2.1667 & 0.28868 & 3 & & & \\
\cline { 2 - 9 } & School level & 2.2273 & 0.47107 & 33 & & & \\
\cline { 2 - 9 }
\end{tabular}




\begin{tabular}{|c|c|c|c|c|c|c|c|}
\hline & Professional & 2.3333 & 0.38832 & 8 & & & \\
\hline \multirow{2}{*}{$\begin{array}{c}\text { Number of } \\
\text { Members earning } \\
\text { in the family }\end{array}$} & 01 & 2.419 & 0.39705 & 105 & & & \\
\hline & 02 & 2.2456 & 0.35298 & 19 & 0.129 & 2.084 & NS \\
\hline \multirow{4}{*}{$\begin{array}{c}\text { Monthly } \\
\text { Income of Family }\end{array}$} & Below Rs.50K & 2.3241 & 0.41005 & 72 & & & \\
\hline & Rs.50K- Rs.1L & 2.5784 & 0.34386 & 34 & 0.004 & 4.636 & $\mathrm{~S}$ \\
\hline & Rs.1L- Rs.2L & 2.3846 & 0.33599 & 13 & & & \\
\hline & Above Rs.2L & 2.1111 & 0.13608 & 6 & & & \\
\hline \multirow{5}{*}{$\begin{array}{l}\text { Occupational } \\
\text { Status }\end{array}$} & Students & 2.35 & 0.42637 & 10 & 0.842 & & \\
\hline & Employee & 2.3792 & 0.36814 & 69 & & \multirow{2}{*}{0.353} & \multirow{2}{*}{ NS } \\
\hline & Business & 2.4167 & 0.44171 & 22 & & & \\
\hline & Unemployed & 2 & 0 & 1 & & & \\
\hline & Others & 2.4275 & 0.43177 & 23 & & & \\
\hline \multirow{3}{*}{ Area of residence } & Rural & 2.4167 & 0.38404 & 22 & & & \\
\hline & Semi-urban & 2.378 & 0.42983 & 41 & 0.933 & 0.07 & $\mathrm{NS}$ \\
\hline & Urban & 2.3871 & 0.37907 & 62 & & & \\
\hline
\end{tabular}

Source: (primary data -Computed) NS- Not significant, S- Significant

From table 4.3 , it is observed that all the significant values are less than F values, accept the $\mathrm{H} 0$ and reject $\mathrm{H} 1$. Thus null hypothesis is accepted. Hence the impact of demographic variables on banc assurance is insignificant.

\section{CONCLUSION}

In a nutshell, it could be concluded that customers are having knowledge about banc assurance as a source for purchasing the insurance policies. Respondents in the city of Kurnool in Andhra Pradesh State are very much in favour of banc assurance in which they have their bank accounts. The primary reason behind opting banc assurance as a medium of purchasing insurance policies is the existing relationship with bank and their reputation so that there is a full security will available for their investment.

\section{SUGGESTIONS}

1. Banc assurance is still at emerging state only in India, if it is nurtured suitably, banks can contribute hugely to the development of insurance industry.

2. It suggested that banks must focus on creating awareness about banc assurance in the rural areas and among illiterate people in order to increase their business.

3. It is also advised, that banks must also motivate their existing customers to purchase the insurance policies via banc assurance as the security provided for their investment is very high.

\section{LIMITATIONS OF THE STUDY}

The following are the limitations of the study:

1. The study covers a sample of 125 respondents in the Kurnool District of Andhra Pradesh State due to time constraint and hence the conclusions on banc assurance cannot be generalised.

2. The study is based on the primary data by collecting opinions of the respondents and it may vary from time to time.

\section{REFERENCES}

1. Carson, C. (2002). Agent discretion and the choice of insurance marketing system. $\neg$ Journal of Law and Economics, 39(2), 627-632.

2. Ostaszewski, K. (2003). Is life insurance a human capital derivatives business? Journal of Insurance, 26, 1-14.

3. Chevalier, M., Launay, C., \& Mainguy, B. (2005). Analysis of banc assurance and its status around world. Paris La Defensecedex , 1-39.

4. Subramaniam, Banc assurance model has a potential to mobilise, Volume-14(1), 2005.

5. Karunagaran, Banc assurance a feasible strategy for banks in India, A publisher for research motivation, Volume-5(9), September-2006.

6. Aggarwal, Distribution of Life insurance products in India, International journal for research and development, 2007.

7. Anja et al, The effective of banc assurance on the financial performance of commercial banks, College of Humanities and Social Sciences(CHSS), 2010.

8. Chiang Ku Fan and Hungchain Lai and Wen Chin Lu, An evaluation of key factors for banc assurance success, International Journal of Application or Innovation in Engineering and Management(IJAIEM), Volume-2, December-2013.

9. Krishnamoorthy, Banc assurance is the most cost-effective channel to make products available to masses, A publisher for research motivation, Volume-5(9), September-2005.

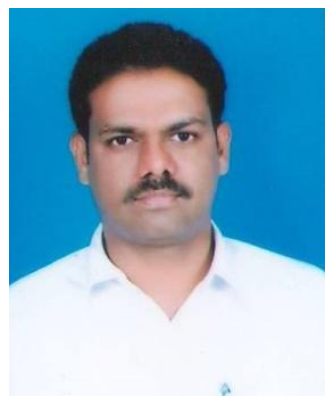

Dr.T. Narayana Reddy M.A(Eco), M.B.A, Ph.D., possessing an experience of 15 years in teaching and 10 years of experience in Research.. He handled the various position as NSS Program Coordinator, JNTUA Ananthapuramu, Public Relation Officer, JNTUA, Officer In charge of Hostels, JNTUA CEA, Head Of the Department, Department Of Humanities, JNTUA CEA, Student Activities Coordinator, JNTUA CE Pulivendula, Chairman, Board of Studies (UG) - Department of Humanities, JNTUA, Member, Board of Studies (PG) - MBA \& MBA(Fintech), JNTUA, Member, Board of Studies (PG) - various Universities \& Autonomous Colleges. Presently he is Additional Controller of Examinations, JNTU Anantapur. He published 25 International journals and 7 National Journals and attended 8 International 
Impact Of Banc Assurance On Customers In Purchasing Insurance Policies With Special Reference To Kurnool District Of Andhra Pradesh

Conferences and 10 National conferences. He is Life Member of Indian Economic Association (IEA). Technological University, Ananthapuramu. and also working as Assistant Professor in Rajeev Gandhi Memorial College of Engineering and Technology. She has published four international journals and three international conferences. She is the member of Hyderabad Management Association (HMA). 